\title{
Respon Perkecambahan Polen Pepaya IPB 6 dan IPB 9 terhadap Penyimpanan pada Suhu Rendah
}

\author{
Response of Papaya Pollen Germination IPB 6 and IPB 9 to Storage at Low Temperature \\ Fidianinta $^{1}$, Ketty Suketi $^{1 *}$, dan Winarso D. Widodo ${ }^{1}$ \\ Diterima 25 November 2014/Disetujui 27 Februari 2015
}

\begin{abstract}
An experiment was conducted to study the germination and storability of papaya pollen IPB 6 and IPB 9 stored for 4 weeks at 3 levels of low temperature. The experiment was conducted at the Laboratory of Microtechnic and Laboratory of Biophysics and Reproductive Biology, Bogor Agricultural University in the month of April to June 2014. Three variables were observed in this experiment: the germination rate, pollen diameter, and length of pollen. The experimental results showed that storage temperature affected the three variables observed. The best germination for IPB 6 was indicated by pollen storage at $10^{\circ} \mathrm{C}(23.1 \%)$ while for IPB 9 was indicated by pollen stored at 5 ${ }^{0} \mathrm{C}(30.7 \%)$. The longest pollen tube of IPB 6 after storage for 4 weeks was indicated by pollen stored at $-20^{\circ} \mathrm{C}(63 \mu \mathrm{m})$ while for IPB 9, indicated by pollen stored at $10^{\circ} \mathrm{C}(47.72 \mu \mathrm{m})$. The experimental results showed that there was no corellation between pollen diameter and length of pollen tube with pollen germination in papaya pollen of IPB 6 dan IPB 9.
\end{abstract}

Key words: diameter pollen, pollen tube, germination, storability

\begin{abstract}
ABSTRAK
Percobaan dilakukan untuk mempelajari daya simpan dan daya berkecambah polen pepaya IPB 6 dan IPB 9 yang disimpan pada suhu $5{ }^{\circ} \mathrm{C}, 10{ }^{\circ} \mathrm{C}$, dan $-20{ }^{\circ} \mathrm{C}$ dengan waktu penyimpanan $0-4$ minggu. Percobaan dilaksanakan di Laboratorium Mikroteknik dan Laboratorium Biofisik dan Biologi Reproduksi, Institut Pertanian Bogor pada bulan April-Juni 2014. Tiga variabel yang diamati pada percobaan ini adalah daya berkecambah, diameter polen dan panjang polen. Hasil percobaan menunjukkan bahwa suhu penyimpanan mempengaruhi ketiga variabel yang diamati. Daya berkecambah terbaik untuk pepaya IPB 6 ditunjukkan oleh polen yang disimpan pada $10{ }^{\circ} \mathrm{C}(23.1 \%)$ sedangkan untuk IPB 9 ditunjukkan oleh polen yang disimpan pada $5{ }^{0} \mathrm{C}(30.7 \%)$. Tabung Polen pepaya terpanjang setelah disimpan selama 4 minggu pada IPB 6 ditunjukkan oleh polen yang disimpan pada $-20{ }^{\circ} \mathrm{C}(63 \mu \mathrm{m})$ sedangkan untuk IPB 9 ditunjukkan oleh polen yang disimpan pada $10{ }^{\circ} \mathrm{C}(47.72 \mu \mathrm{m})$. Hasil percobaan menunjukkan bahwa tidak ada hubungan antara diameter dan panjang tabung polen dengan daya berkecambah pada polen pepaya IPB 9 dan IPB 6 .
\end{abstract}

Kata kunci: daya berkecambah, daya simpan, diameter polen, tabung polen

\section{PENDAHULUAN}

Pepaya merupakan salah satu tanaman buah yang banyak ditanam oleh masyarakat Indonesia. Menurut Suketi (2011) pepaya memiliki permasalahan dalam hal pengembangan, diantaranya produktivitas yang masih rendah dan beberapa varietas unggul belum memenuhi kriteria yang disukai konsumen karena mutu buah yang belum optimum. Suketi et al. (2010) menyatakan bahwa kualitas buah pepaya yang sesuai dengan kriteria yang disukai konsumen dapat diperoleh dengan cara pengendalian penyerbukan. Penyerbukan polen dari genotipe pepaya lain pada bunga betina diharapkan dapat menghasilkan peningkatan kualitas buah pepaya betina. Denney (1992) menjelaskan

${ }^{1}$ Departemen Agronomi dan Hortikultura, Fakultas Pertanian, Institut Pertanian Bogor

(Bogor Agricultural University), Jl. Meranti, Kampus IPB Darmaga, Bogor 16680, Indonesia

Telp.\&Faks.62-251-8629353.*Email korespondensi: kettysuketi@yahoo.com 
bahwa perbaikan kualitas buah dapat dilakukan dengan efek metaxenia yaitu suatu keadaan dimana serbuk sari berpengaruh langsung terhadap jaringan tetua betina khususnya pada endosperma buah. Fenomena ini dapat dilihat pada ukuran, warna, bentuk serta komposisi kimia dari bagian buah.

Penelitian yang telah dilakukan oleh Febriyanti et al. (2010) menunjukkan terjadinya peningkatan bobot buah IPB 9 yang dihasilkan dari persilangan antara IPB 9 dan polen yang bersumber dari IPB 3. Baskorowati (2006) juga menunjukkan bahwa pengendalian penyerbukan merupakan salah satu kegiatan strategis pemuliaan tanaman dengan tujuan menyatukan alel terbaik dari kisaran tanaman yang telah terpilih dan menyediakan genotipe baru yang baik. Hasil penelitian yang telah dilakukan oleh Sulistyo et al. (2006) menunjukkan bahwa serbuk sari yang berasal dari pepaya IPB 6 dapat meningkatkan rasa manis dan tebal daging buah pada pepaya betina IPB 1. Nadila (2014) menjelaskan bahwa pada buah naga pe-nyerbukan merupakan faktor penting dalam produksi karena penyerbukan mempengaruhi produktivitas dan kualitas. Semakin banyak polen yang diserbukkan maka semakin besar ukuran buah yang terbentuk karena semakin banyak biji yang terbentuk. Selain itu menurut Widiastuti dan Palupi (2008), pada buah kelapa sawit semakin banyak polen yang digunakan cenderung meningkatkan pembentukan buah normal.

Polen merupakan salah satu komponen yang berperan dalam penyerbukan. Pengecambahan polen memerlukan media yang sesuai dengan polen yang akan dikecambahkan. Salah satu metode pengecambahan adalah dengan cara pengecambahan polen secara in vitro. Menurut Warid dan Palupi (2009) metode ini tidak dapat digunakan secara umum karena setiap tanaman memerlukan media perkecambahan polen yang berbeda, sehingga diperlukan komposisi dan konsentrasi bahan kimia yang tepat. Media perkecambahan polen PGM dan BK (Brewbaker dan Kwack) tidak menunjukkan adanya hasil yang berbeda pada daya berkecambah famili Poaceae, Euphorbiaceae, Solanaceae dan Myrtaceae.

Salah satu cara untuk menjaga ketersediaan polen adalah dengan penyimpanan. Menurut Hoekstra (1995) polen yang dikumpulkan dan disimpan dapat digunakan untuk keperluan pemuliaan. Meskipun jumlah polen yang berperan dalam pembentukan individu baru hanya sedikit, namun hal tersebut akan lebih efisien apabila dilakukan pengumpulan polen dalam jumlah yang lebih besar untuk memastikan ketersediaan polen dalam jangka waktu yang cukup lama. Sabran et al. (2012) menyatakan bahwa penyerbukan pada bunga bergantung pada ketersediaan polen. Setelah penggunaan apabila polen tidak habis dipakai dapat disimpan.

Sari et al. (2010) menyatakan bahwa lama simpan serbuk sari dapat ditingkatkan dengan mengendalikan faktor-faktor yang mempengaruhi viabilitasnya. Khan dan Perveen (2006) menjelaskan bahwa salah satu faktor yang paling mempengaruhi dalam viabilitas polen pada saat penyimpanan adalah suhu. Setiawan dan Ruskandi (2005) juga menyatakan bahwa tidak semua polen habis dipakai dalam 1 hari pada persilangan buatan, bergantung pada jumlah bunga betina yang sudah siap untuk diserbuki, sehingga polen perlu disimpan dan proses penyimpanan polen akan mempengaruhi viabilitasnya. Berdasarkan penelitian yang telah dilakukan oleh Perveen (2007), mempertahankan kapasitas perkecambahan polen yang disimpan dapat bermanfaat untuk menghemat waktu dalam program pemuliaan dan juga dalam perbaikan tanaman. Percobaan yang telah dilakukan oleh Perveen et al. (2007) menunjukkan bahwa faktor mayor yang mempengaruhi kondisi polen adalah suhu dengan hasil polen pepaya yang disimpan pada suhu $-60{ }^{\circ} \mathrm{C}$ menghasilkan viabilitas terbaik yaitu $60 \%$ setelah disimpan selama 48 minggu. Penelitian ini bertujuan mempelajari pengaruh beberapa suhu rendah terhadap daya simpan dan daya berkecambah polen pepaya IPB 6 dan IPB 9 .

\section{BAHAN DAN METODE}

Percobaan ini dilaksanakan di Laboratorium Mikroteknik dan Laboratorium Biofisik dan Biologi Reproduksi, Departemen Agronomi dan Hortikultura, Fakultas Pertanian, Institut Pertanian Bogor pada bulan April sampai dengan bulan Juni 2014. Bahan yang digunakan adalah polen pepaya yang diambil dari 2 genotipe berbeda yaitu IPB 6 dan IPB 9 . Polen diperoleh dari bunga pepaya yang berada di Kebun Percobaan Pusat Kajian 
Hortikultura Tropika (PKHT) IPB Tajur dan Pasir Kuda. Bunga dipanen pada saat pagi hari sekitar pukul 08.00 WIB sampai 09.00 WIB pagi. Media perkecambahan polen pepaya yang digunakan adalah Brewbaker dan Kwack yang terdiri atas $0.01 \mathrm{~g} \mathrm{H}_{3} \mathrm{BO}_{3}, 0.03 \mathrm{~g}$ $\mathrm{Ca}\left(\mathrm{NO}_{3}\right)_{2} 4 \mathrm{H}_{2} \mathrm{O}, 0.02 \mathrm{~g} \mathrm{MgSO}_{4} 7 \mathrm{H}_{2} \mathrm{O}, 0.01 \mathrm{~g}$ $\mathrm{KNO}_{3}, 10 \%$ sukrosa dan $100 \mathrm{ml}$ aquades.

Percobaan dilakukan dengan menggunakan Rancangan Acak Lengkap (RAL) faktor tunggal dengan 2 genotipe dan 3 taraf perlakuan yaitu suhu $-20{ }^{0} \mathrm{C}, 5{ }^{\circ} \mathrm{C}$ dan $10{ }^{\circ} \mathrm{C}$ dan dengan masing-masing 3 ulangan sehingga menghasilkan 18 satuan percobaan. Setiap kaca preparat merupakan satu unit percobaan dan dalam 1 kaca preparat dibutuhkan 4 bidang pandang kemudian dalam 1 bidang pandang jumlah polen yang diamati terdiri atas 20 polen.

Bunga pepaya yang dipanen adalah bunga yang belum mengalami antesis kemudian dimasukkan ke dalam cool box untuk segera dieskstrak polennya di laboratorium. Polen yang telah diekstrak kemudian dimasukkan ke dalam microtube kemudian disimpan dalam 3 lemari pendingin dengan suhu yang berbeda yaitu $-20{ }^{0} \mathrm{C}, 5{ }^{\circ} \mathrm{C}$, $10{ }^{\circ} \mathrm{C}$, sedangkan untuk kontrol yaitu polen yang diamati langsung setelah dipanen dari kebun. Berdasarkan penelitian yang dilakukan oleh Agustin (2013), sebelum diekstraksi antera dikeringkan dahulu dalam ruangan $\mathrm{AC}$ selama 24 jam. Ekstraksi polen dari antera dilakukan dengan meng-gunakan kain kasa nilon halus dengan ukuran $45 \mu \mathrm{m}$ dan box yang dimodifikasi sebagai ekstraktor polen.

Media perkecambahan dimasukkan ke dalam lemari pendingin atau freezer agar kualitas dan kesterilannya tetap terjaga dan media tersebut siap digunakan untuk perkecambahan. Menurut Widiastuti dan Palupi (2008), polen yang disimpan di dalam lemari pendingin dikeluarkan lalu didiamkan selama 30 menit kemudian dikecambahkan dalam media yang telah disediakan. Agustin (2013) menyatakan bahwa polen yang ingin dikecambahkan untuk segera ditaburkan di gelas objek kemudian ditetesi media perkecambahan dan diinkubasi selama 4 jam.

Pengamatan dilakukan setiap minggu selama 4 minggu. Pengamatan pertama dilakukan dengan mengukur daya berkecambah polen sebelum disimpan pada hari ke-0 sebagai kontrol. Pengamatan selanjutnya dilakukan pada 7, 14, 21, dan 28 hari setelah penyimpanan polen. Perkecambahan polen diamati dengan menggunakan mikroskop cahaya Olympus BX 51 dengan perbesaran 200 kali. Setiap ulangan merupakan 1 deck glass yang terdiri atas 4 bidang pandang yang akan diamati parameternya. Setiap paramater memiliki perbedaan kriteria untuk diamati.

Peubah yang diamati adalah: (1) daya berkecambah, tabung polen yang panjangnya melebihi diameternya dapat dikategorikan polen tersebut telah berkecambah (Wang et al., 2005). Perkecambahan polen dihitung dengan satuan persen. Polen yang pecah tidak dihitung sebagai polen yang berkecambah. Berdasarkan penelitian yang telah dilakukan oleh Raganata (2006) daya berkecambah polen diamati dengan mikroskop dengan perhitungan jumlah polen yang berkecambah dibagi dengan jumlah polen yang diamati dalam satu bidang kemudian dikali dengan 100\%. (2) Panjang tabung polen, pengukuran dilakukan dengan cara menggunakan mikroskop yang dilengkapi dengan mikrometer pada perbesaran 200 kali. (3) Diameter polen, pengukuran diameter polen tidak jauh berbeda dengan pengukuran panjang polen yaitu menggunakan mikroskop dan perbesaran yang sama setelah diinkubasi selama 4 jam.

Data percobaan perkecambahan polen pepaya dianalisis dengan Uji-F menggunakan software SAS pada selang kepercayaan 95\% $(\alpha=5 \%)$. Apabila terdapat perbedaan yang nyata pada taraf $5 \%$ akan dilanjutkan dengan analisis Duncan Multiple Range Test (DMRT).

\section{HASIL DAN PEMBAHASAN}

\section{Daya Berkecambah Polen}

Hasil pengamatan polen pepaya IPB 6 dan IPB 9 yang telah disimpan selama 4 minggu menunjukkan respon perkecambahan yang berbeda pada masing-masing suhu. Menurut Wang et al. (2005), tabung polen yang panjangnya melebihi diameternya dapat dikategorikan polen tersebut telah berkecambah. Hasil penelitian menunjukkan bahwa suhu dan lama penyimpanan berpengaruh terhadap daya berkecambah polen pepaya IPB 6 dan IPB 9 (Tabel 1). Berdasarkan hasil percobaan, polen pepaya IPB 6 segar atau polen yang dikecambahkan pada suhu ruang 
memiliki daya berkecambah sebesar $17.8 \%$ sedangkan untuk polen pepaya IPB 9 sebesar $22.1 \%$.

Sampai penyimpanan minggu ke-4, polen pepaya IPB 6 yang disimpan dalam suhu $10{ }^{0} \mathrm{C}$ dan $-20{ }^{0} \mathrm{C}$ mengalami peningkatan persentasi daya berkecambah dari minggu sebelumnya dan memiliki persentase daya berkecambah yang lebih baik dibandingkan polen pepaya IPB 6 yang disimpan pada suhu $5{ }^{0} \mathrm{C}$. Hal ini menunjukkan bahwa polen pepaya IPB 6 masih dapat berkecambah dengan baik sampai 4 minggu apabila disimpan pada suhu $10{ }^{0} \mathrm{C}$ dan $-20{ }^{0} \mathrm{C}$. Menurut Sari et al. (2010), adanya kecenderungan peningkatan viabilitas pada penyimpanan minggu ke-4 berkaitan dengan dormansi serbuk sari terhadap suhu rendah. Suhu rendah dapat memecahkan dormansi karena adanya adaptasi serbuk sari pada kondisi lingkungan yang dingin atau beku.

Polen pepaya IPB 9 segar memiliki daya berkecambah lebih tinggi $4.31 \%$ dibandingkan dengan polen pepaya IPB 6 segar. Polen pepaya IPB 9 mengalami penurunan persentase daya berkecambah pada penyimpanan minggu ke-4 namun polen yang telah disimpan selama 4 minggu dalam suhu $5{ }^{\circ} \mathrm{C}$ memiliki nilai persentase daya berkecambah yang lebih baik dibandingkan dengan polen pepaya IPB 9 yang disimpan dalam suhu $10{ }^{\circ} \mathrm{C}$ dan $-20{ }^{\circ} \mathrm{C}$, bahkan pada suhu $-20{ }^{\circ} \mathrm{C}$ daya berkecambah polen pepaya IPB 9 menjadi $0 \%$. Berdasarkan penelitian Handayani et al. (2012), viabilitas polen Hemerocallis fulva L. yang disimpan pada suhu $4{ }^{0} \mathrm{C}$ menurun hingga penyimpanan pada minggu ke-4 sedangkan penelitian Martinez-Gomez et al. (2002) menunjukkan bahwa penyimpanan polen almond (Prunus dulcis) pada suhu $4 \mathrm{C}$ tidak menujukkan penurunan viabilitas yang signifikan selama 2 bulan.

Penurunan persentase daya berkecambah pada minggu ke-4 kemungkinan disebabkan oleh pengeringan polen pada saat sebelum polen disimpan dalam pendingin. Menurut Daher et al. (2008), polen yang dikeringkan selama 24 jam sebelum disimpan dalam pendingin menyebabkan daya berkecambah berkurang sebanyak 20\%, sedangkan jika dikeringkan selama 2 jam maka daya berkecambahnya akan sama dengan daya berkecambah polen segar. Hoekstra dan Bruinsma (1975) juga menyatakan bahwa pada umumnya polen trinukleat lebih sulit untuk disimpan, hal ini karena kemampuan hidup polen trinukleat dipengaruhi oleh kecepatan respirasi. Polen trinukleat melakukan respirasi 2 sampai 3 kali lebih cepat dibandingkan dengan polen binukleat.

Tabel 1 menunjukkan persentase daya berkecambah polen pepaya IPB 6 dan IPB 9 tidak konsisten. Masing-masing genotipe memiliki respon yang berbeda, terdapat peningkatan dan penurunan persentase daya berkecambah pada setiap suhu dan umur penyimpanan. Penelitian yang telah dilakukan oleh Baki (1992) pada buah tomat menunjukkan bahwa daya berkecambah polen akan menurun seiring bertambahnya waktu penyimpanan dan suhu penyimpanan yang terbaik adalah $6{ }^{\circ} \mathrm{C}$. Menurut Handayani et al. (2012) peningkatan dan penurunan viabilitas setiap minggunya pada polen Hemerocallis fulva $\mathrm{L}$, berkaitan dengan adaptasi pada suhu dan lama penyimpanan. Selain itu Boavida dan McCormick (2007) juga menjelaskan keberadaan cahaya mempengaruhi perkecambahan. Perkecambahan yang mendapatkan cahaya menghasilkan nilai daya berkecambah di atas $80 \%$.

Mortazavi et al. (2010) menyatakan bahwa perbedaan daya berkecambah antar kultivar dapat disebabkan oleh variabilitas genetik. Berdasarkan penelitian yang dilakukan oleh Akond et al. (2012) pada Lagerstroemia spp., penyimpanan polen yang layak tidak lebih dari 75 sampai 100 hari sehingga akan membuat kegiatan hibridisasi yang dilakukan oleh para pemulia menjadi cukup efisien dalam penggunaan polen meskipun lokasi yang berjauhan.

\section{Diameter Polen}

Hasil percobaan menunjukkan bahwa suhu dan lama penyimpanan mempengaruhi ukuran diameter polen pepaya IPB 6 . Perbedaan ukuran antara kedua genotipe lebih terlihat jelas pada penyimpanan minggu ke-4 dimana diameter polen pepaya IPB 6 lebih kecil dibandingkan minggu sebelumnya, namun polen pepaya IPB 9 hampir sama pada setiap minggunya. Diameter polen pepaya IPB 6 dan IPB 9 segar atau tanpa perlakuan penyimpanan pada percobaan ini masingmasing sebesar $31.31 \mu \mathrm{m}$ dan $35.03 \mu \mathrm{m}$. 
Tabel 1. Daya berkecambah polen pepaya IPB 6 dan IPB 9 selama 4 minggu penyimpanan

\begin{tabular}{ccccccc}
\hline \multirow{2}{*}{$\begin{array}{c}\text { Umur Simpan Polen } \\
\text { (minggu) }\end{array}$} & $10^{\circ} \mathrm{C}$ & $5^{\circ} \mathrm{C}$ & $-20{ }^{\circ} \mathrm{C}$ & $10^{0} \mathrm{C}$ & $5{ }^{\circ} \mathrm{C}$ & $-20{ }^{\circ} \mathrm{C}$ \\
& $(\%)$ & $(\%)$ & $(\%)$ & $(\%)$ & $(\%)$ & $(\%)$ \\
\hline 1 & $13.7 \mathrm{a}$ & $10.5 \mathrm{a}$ & $12.0 \mathrm{a}$ & $23.5 \mathrm{a}$ & $39.6 \mathrm{a}$ & $26.7 \mathrm{a}$ \\
2 & $31.5 \mathrm{a}$ & $11.7 \mathrm{~b}$ & $8.9 \mathrm{~b}$ & $43.8 \mathrm{a}$ & $14.9 \mathrm{~b}$ & $35.4 \mathrm{ab}$ \\
3 & $6.7 \mathrm{~b}$ & $6.7 \mathrm{~b}$ & $66.7 \mathrm{a}$ & $43.6 \mathrm{a}$ & $20.7 \mathrm{~b}$ & $21.2 \mathrm{~b}$ \\
4 & $23.1 \mathrm{a}$ & $11.1 \mathrm{a}$ & $22.4 \mathrm{a}$ & $20.3 \mathrm{ab}$ & $30.7 \mathrm{a}$ & $0.0 \mathrm{~b}$ \\
\hline
\end{tabular}

Keterangan : Angka yang diikuti dengan huruf kecil yang sama pada baris yang sama dan genotipe yang sama tidak berbeda nyata pada uji Duncan taraf 5\%

Tabel 2. Diameter polen pepaya IPB 6 dan IPB 9 selama 4 minggu penyimpanan

\begin{tabular}{ccccccc}
\hline $\begin{array}{c}\text { Umur Simpan Polen } \\
\text { (minggu) }\end{array}$ & $\begin{array}{c}10^{\circ} \mathrm{C} \\
(\mu \mathrm{m})\end{array}$ & $\begin{array}{c}5^{0} \mathrm{C} \\
(\mu \mathrm{m})\end{array}$ & $\begin{array}{c}-20^{0} \mathrm{C} \\
(\mu \mathrm{m})\end{array}$ & $\begin{array}{c}10^{0} \mathrm{C} \\
(\mu \mathrm{m})\end{array}$ & $\begin{array}{c}5{ }^{\circ} \mathrm{C} \\
(\mu \mathrm{m})\end{array}$ & $\begin{array}{c}-20^{0} \mathrm{C} \\
(\mu \mathrm{m})\end{array}$ \\
\hline 1 & 32.93 & 33.09 & 32.51 & 34.15 & 33.63 & 33.65 \\
2 & 31.32 & 31.05 & 32.89 & 32.38 & 33.23 & 34.24 \\
3 & 30.11 & 32.21 & 29.51 & 33.38 & 32.60 & 33.42 \\
4 & 31.18 & 28.83 & 28.80 & 32.88 & 33.76 & 34.19 \\
\hline
\end{tabular}

Tabel 2 menunjukkan terdapat perubahan ukuran pada polen pepaya IPB 6 setelah disimpan selama 4 minggu pada suhu $5{ }^{\circ} \mathrm{C}$ dan $-20{ }^{0} \mathrm{C}$ sedangkan pada polen pepaya IPB 9 tidak terlihat perubahan ukuran yang signifikan pada setiap suhu dan minggu penyimpanan. Menurut Gammon (2009), tidak ada hubungan antara ukuran polen dengan persentase viabilitas pada Fallopia japonica. Penelitian yang telah dilakukan oleh Knight $e t$ al. (2010) menunjukkan tanaman angiospermae memiliki ukuran polen terkecil sebesar 17 $\mu \mathrm{m}$ dan yang terbesar sebesar $150 \mu \mathrm{m}$ dengan rata-rata ukuran sebesar $48.3 \mu \mathrm{m}$. Kelly et al. (2002) juga melakukan penelitian yang menunjukkan bahwa pada Mimulus guttatus polen yang layak merupakan polen yang memiliki ukuran berkisar antara 25 sampai 35 $\mu \mathrm{m}$ dan polen yang tidak layak memiliki ukuran 10 sampai $25 \mu \mathrm{m}$.

\section{Panjang Tabung Polen}

Hasil pengamatan pada polen pepaya IPB 6 yang telah disimpan selama 4 minggu dalam 3 suhu rendah menunjukkan bahwa suhu dan lama penyimpanan tidak berpengaruh terhadap panjang tabung polen pepaya IPB 6 , sedangkan pada polen pepaya IPB 9 suhu dan lama penyimpanan berpengaruh terhadap panjang tabung polen (Tabel 3). Berdasarkan hasil percobaan, panjang tabung polen pepaya IPB 6 segar atau tanpa perlakuan penyimpanan sebesar 128.04 $\mu \mathrm{m}$ sedangkan panjang tabung polen pepaya IPB 9 segar sebesar $138.81 \mu \mathrm{m}$.

Ukuran panjang tabung polen IPB 6 mengalami penurunan sampai pada penyimpanan minggu ke-4 dengan nilai panjang tabung polen tertinggi ditunjukkan oleh polen yang disimpan pada suhu $-20{ }^{\circ} \mathrm{C}$. Tabung polen pepaya IPB 9 segar berukuran sebesar $138.81 \mu \mathrm{m}$, ukuran ini tidak jauh berbeda dengan polen pepaya IPB 6 segar. Serupa dengan polen pepaya IPB 6, pada tiap suhu penyimpanan, panjang tabung polen pepaya IPB 9 mengalami penurunan sampai penyimpanan minggu ke-4 dengan nilai panjang tabung polen pepaya IPB 9 tertinggi diperoleh dari polen yang disimpan dalam suhu $10{ }^{\circ} \mathrm{C}$. Nilai panjang tabung polen pada Tabel 3 tidak menunjukkan adanya hubungan dengan persentase daya berkecambah pada Tabel 1. Hal ini dapat dilihat dari persentase daya berkecambah tertinggi pada polen pepaya IPB 6 dan IPB 9 bukanlah yang memiliki nilai panjang tabung polen tertinggi sampai pada penyimpanan minggu ke-4.

Penelitian yang telah dilakukan oleh Boavida dan McCormick (2007) menunjukkan bahwa pada Arabidopsis thaliana daya berkecambah polen yang tinggi memiliki nilai panjang tabung polen yang rendah pada ekotipe Columbie sedangkan pada ekotipe Ler 
yang memiliki daya berkecambah rendah menunjukkan nilai panjang tabung polen yang lebih tinggi. Penelitian Widiastuti dan Palupi (2008) juga menunjukkan bahwa pada polen kelapa sawit yang telah disimpan selama 6 bulan menunjukkan viabilitas yang masih baik tetapi panjang tabung polen selama per- kecambahan berkurang yang mengindikasikan terjadinya penurunan vigor polen. Kamrani (2012) menambahkan bahwa tidak ada hubungan yang signifikan antara persentase perkecambaha dengan per-tumbuhan panjang tabung polen (Tabel 3).

Tabel 3. Panjang tabung polen pepaya IPB 6 dan IPB 9 selama 4 minggu penyimpanan

\begin{tabular}{|c|c|c|c|c|c|c|}
\hline \multirow{2}{*}{$\begin{array}{c}\text { Umur Simpan Polen } \\
(\text { minggu })\end{array}$} & \multicolumn{3}{|c|}{ IPB 6} & \multicolumn{3}{|c|}{ IPB 9} \\
\hline & $\begin{array}{l}10^{0} \mathrm{C} \\
(\mu \mathrm{m})\end{array}$ & $\begin{array}{c}5^{0} \mathrm{C} \\
(\mu \mathrm{m})\end{array}$ & $\begin{array}{c}-20^{0} \mathrm{C} \\
(\mu \mathrm{m})\end{array}$ & $\begin{array}{l}10^{0} \mathrm{C} \\
(\mu \mathrm{m})\end{array}$ & $\begin{array}{c}5^{0} \mathrm{C} \\
(\mu \mathrm{m})\end{array}$ & $\begin{array}{c}-20{ }^{0} \mathrm{C} \\
(\mu \mathrm{m})\end{array}$ \\
\hline 1 & $118.69 \mathrm{a}$ & $87.85 \mathrm{a}$ & $65.38 \mathrm{a}$ & $83.87 \mathrm{a}$ & $59.36 \mathrm{a}$ & $89.09 a$ \\
\hline 2 & $114.16 \mathrm{a}$ & $135.24 \mathrm{a}$ & $120.49 a$ & $144.49 \mathrm{a}$ & $57.96 a$ & $181.45 a$ \\
\hline 3 & $113.57 \mathrm{a}$ & $211.52 \mathrm{a}$ & $211.38 \mathrm{a}$ & $74.28 \mathrm{a}$ & 48.70ab & $32.19 b$ \\
\hline 4 & $54.37 \mathrm{a}$ & $30.85 b$ & $63.00 \mathrm{a}$ & $47.72 \mathrm{a}$ & $41.27 \mathrm{a}$ & $24.88 \mathrm{a}$ \\
\hline
\end{tabular}

Keterangan: Angka yang diikuti dengan huruf kecil yang sama pada baris yang sama dan genotipe yang sama tidak berbeda nyata pada uji Duncan taraf 5\%

Suhu di atas $24{ }^{0} \mathrm{C}$ dan di bawah $20{ }^{0} \mathrm{C}$ memiliki dampak yang buruk pada pertumbuhan tabung polen begitu juga dengan perkecambahannya. Suhu $24{ }^{0} \mathrm{C}$ atau lebih, meskipun tabung polen terlihat tumbuh lebih cepat, perkecambahan polen berkurang dan sekitar 50\% tabung polen menunjukkan morfologi yang abnormal dan cacat. Suhu di bawah $20{ }^{0} \mathrm{C}$ sangat menghambat perkecambahan dan banyak butir polen yang pecah. Hal ini sangat penting untuk menjaga suhu selama jalannya penelitian, karena variasi suhu sewaktu-waktu dapat menyebabkan tabung polen tertahan ataupun memiliki morfologi yang abnormal (Boavida dan McCormick 2007). Hal ini menyebabkan rendahnya nilai panjang tabung polen karena pada saat pengamatan di laboratorium suhu ruangan sebesar $27{ }^{0} \mathrm{C}$.

Hedhly et al. (2004) menyatakan bahwa meskipun suhu yang bertambah tinggi dapat menurunkan daya berkecambah, namun jumlah tabung polen yang berada pada putik secara bertahap akan menurun dimana pertumbuhan tabung polen juga akan semakin cepat dan pada waktu tertentu tabung polen yang sampai ke dasar putik akan mencapai jumlah maksimum dan berhenti. Jumlah ini dipengaruhi oleh genotipe atau suhu. Menurut Kakani et al. (2002) suhu optimum untuk perkecambahan dan pertumbuhan tabung polen adalah sekitar $25{ }^{0} \mathrm{C}$ sampai $30{ }^{0} \mathrm{C}$ jika lebih dari ini akan mengurangi jumlah polen yang berkecambah dan pertumbuhan tabung polen.

\section{KESIMPULAN}

Polen pepaya IPB 6 yang disimpan selama 4 minggu masih memiliki daya berkecambah yang baik apabila disimpan pada suhu $10{ }^{0} \mathrm{C}$, sedangkan polen pepaya IPB 9 yang disimpan selama 4 minggu masih memiliki daya berkecambah yang baik apabila disimpan pada suhu $5{ }^{\circ} \mathrm{C}$.

\section{DAFTAR PUSTAKA}

Agustin, H. 2013. Pengelolaan polen untuk produksi benih melon hibrida sunrise meta dan orange meta. Tesis. Institut Pertanian Bogor. Bogor.

Akond, A.S.M.G, C.T. Pounders, E.K. Blythe, X. Wang. 2012. Longevity of crapemyrtle pollen stored at different temperatures. Scientia Horticulturae. 139(2012): 5357.

Baki, A.A.A. 1992. Determination of pollen viability in tomatoes. J Amer Soc Hort Sci. 117(3): 473-476.

Baskorowati, L. 2006. Controlled pollination methods for Melaleuca alternifolia (Maiden \& Betche) Cheel. ACIAR Technical Reports. (63): 17p.

Daher, F.B., Y. Chebli, A. Geitmann. 2008. Optimization of conditions for germination of cold storage Arabidopsis 
thaliana pollen. Plant Cell Rep. 28(3): 347-357.

Denney, J.O. 1992. Xenia includes metaxenia. Hort Science. 27(7): 722-728.

Febriyanti, N., S. Sujiprihati, W.D. Widodo. 2010. Kajian metaxenia pada buah pepaya genotipe IPB 9. Di dalam: Utama IMS, A.D. Susila, R. Poerwanto, N.S. Antara, N.K. Putra, K.B. Susrua, editor. Reorientasi Riset untuk Mengoptimalkan Produksi dan Rantai Nilai Hortikultura. Seminar Nasional Hortikultura Indonesia: 20 Nop 25-26: Denpasar. Indonesia, Perhimpunan Hortikultura Indonesia. hlm 111-116. Bogor.

Gammon, M.A. 2009. The Diversity growth and fitness of the invasive plants Fallopia japonica (Japanese Knotweed) and Fallopia xbohemica in the united states (Polygonaceae). Disertasi. University of Massachusetts Boston. Boston (US).

Handayani, N.K.S.D., E. Kriswiyanti, I.A. Astarini. 2012. Uji viabilitas serbuk sari Hemerocallis fulva L. (Liliceae) setelah penyimpanan pada waktu dan suhu yang berbeda. Jurnal Metamorfosa. 1(1): 17-24.

Hedhly, A., J.I. Hormaza, M. Herrero. 2004. Effect of temperature on pollen tube kinetics and dynamics in sweet cherry, Prunus avium (Rosaceae). American Journal of Botany. 91(4): 558-564.

Hoekstra, F.A. 1995. Collecting pollen for genetic resources conservation. Di dalam: Guarino L, Rao R, Reid R, editor. Collecting Plant Genetic Diversity: Technical Guidelines. Fort Collins (USA): IUCN. http://cropgenebank.sgrp.cgiar.org/index . php?.php?option=com_content $\&$ view= article\&id=654. [2 Februari 2014].

Hoekstra, F.A., J. Bruisma. 1975. Respiration and vitality of binucleate and trinucleate pollen. Physiol Plant. 34: 221-225.

Junior, P.C.D., T.N.S. Pereira, M.G. Pereira, F.F. Da Silva, M.D.M. Souza, R.G. Nicoli. 2009. Preferential reproduction mode of hermaphrodite papaya plant. Rev Bras Frutic Jaboticabal. 31(1): 182189.

Kakani, V.G., P.V.V. Prasad, P.Q. Craufurd, T.R. Wheeler. 2002. Response of in vitro pollen germination and pollen tube growth of groundnut (Arachis hypogaea L.) genotypes to temperature. Plant Cell and Environment. 25: 1651-1661.

Kamrani, R. 2012. Study on pollen germination and pollen tube growth of five iranian apricot cultivars on in vitro condition. International Conference on Applied Life Science. Bam Branch. Iran, Turki(TR): INTECH.

Kelly, J.K., A. Rasch, S. Kalisz. 2002. A method to estimate pollen viability from pollen size variation. American Journal of Botany. 89(6): 1021-1023.

Khan, S.A., A. Perveen. 2006. Germination capacity of stored pollen of Abelmoschus esculentus L. (Malvaceae). Pak J Bot. 38(2): 233-236.

Knight, C.A., R.B. Clancy, L. Gotzenberger, L. Dann, J.M. Beaulieu. 2010. On the relationship between pollen size and genome size. Journal of Botany. 2010: 17.

Knowlton, H.E. 1922. Studies in pollen with special reference to longevity. Cornell University. New York (US).

Martinez-Gomez, P., T.M. Gradziel. 2002. Low temperature storage of almond pollen. Hort Science. 37(4): 691-692.

Mortazavi, S.M.H., K. Arzani, A. Moieni. 2010. Optimizing storage and in vitro germination of date Palm (Phoenix dactylifera) pollen. J Agr Sci Tech. (12): 181-189.

Nadila, D. 2014. Fenologi pembungaan dan penyerbukan buah naga Hylocereus undatus, Hylocereus costaricensis dan Selenicereus megalanthus. Skripsi. Institut Pertanian Bogor. Bogor. 
Perveen, A. 2007. Pollen germination capacity, viability and maintanence of Pisium sativum L. (Papilionaceae). Middle - East Journal of Scientific Research. 2(2): 79-81.

Perveen, A., S.A. Khan, R. Abid. 2007. Maintenance of pollen germination capacity of Carica papaya L (Caricaceae). Pak J Bot Sci. 39(5): 1403-1406.

Raganata, A.P. 2006. Kajian pengelolaan serbuk sari kelapa sawit (Elaeis guineensis Jacq.) pisifera. Skripsi. Institut Pertanian Bogor. Bogor.

Sabran, M., E. Gunawan, Hardono, S. Prabawati, J. Pitono, B. Sankarto, I.P. Wardana, H.S. Mamat, R. Rachmat, E. Romjali, S. Pardal, Wachid, R. Hermawanto. 2012. Inovasi Teknologi Membangun Ketahanan Pangan dan Kesejahteraan Petani. IAARD Press. Jakarta.

Sari, N.K.Y., E. Kriswiyanti, I.A. Astarini. 2010. Uji viabilitas dan perkembangan serbuk sari buah naga putih (Hylocereus undatus (Haw.) Britton \& Rose), merah (Hylocereus polyrhizus (Web.) Britton \& Rose) dan super merah (Hylocereus costaricensis (Web.) Britton \& Rose) setelah penyimpanan. J Biologi. 14(2): $39-44$.

Setiawan, O., Ruskandi. 2005. Teknik penyimpanan serbuk sari tiga kultivar kelapa dalam. Bul Teknik Pertanian. 10(1): 37-38.

Suketi, K. 2011. Studi morfologi bunga penyerbukan dan perkembangan buah sebagai dasar pengendalian mutu buah pepaya IPB. Disertasi. Institut Pertanian Bogor. Bogor.

Suketi, K., Sujiprihati S, Handayani TL. 2010. Peningkatan kualitas buah pepaya melalui pengendalian penyerbukan. Di dalam: Utama I.M.S., A.D Susila, R. Poerwanto, N.S. Antara, N.K. Putra, K.B. Susrua, editor. Reorientasi Riset untuk Mengoptimalkan Produksi dan Rantai Nilai Hortikultura. Seminar Nasional Hortikultura Indonesia: 20 Nop 25-26: Denpasar. Indonesia. Perhimpunan Horti-kultura Indonesia. hlm 111-116. Bogor.

Sulistyo, A., S. Sujiprihati, Trikoesomaningtyas. 2006. Studi persilangan efek metaxenia pada pepaya. Di dalam: Dwiyanto K., Agung T, Muladno, Sujiprihati S, Siagian PH, editor. Pemuliaan Sebagai Pendukung Kemandirian dan Ketahanan Pangan 2020. 2006 Agu 25-26: Purwokerto. Indonesia. PERIPI. hlm 282-289. Bogor.

Wang, Q., L. Kong, H. Hao, X. Wang, J. Lin, J Samaj, F. Baluska. 2005. Effects of Brefeldin A on pollen germination and tube growth antagonistic effects on endocytosis and secretion. Plant Physiology. 139: 1692-1703.

Warid. Palupi ER. 2009. Korelasi metode pengecambahan in vitro dan pewarnaan dalam pengujian viabilitas polen. Skripsi. Institut Pertanian Bogor. Bogor.

Widiastuti, A., E.R. Palupi. 2008. Viabilitas serbuk sari dan pengaruhnya terhadap keberhasilan pembentukan buah kelapa sawit (Elaeis guineensis Jacq.) Biodiversitas. 9(1): 35-38. 